\title{
Effects of Cadmium and /or Chromium on reproductive organs and semen profiles of male albino rats
}

\author{
Eman M. Abd Elhafeez ${ }^{1 *}$, Amal A. Halawa ${ }^{1}$, Mohamed F. Hamed ${ }^{2}$, Mamdouh M. Abouelmaged ${ }^{1}$ \\ ${ }^{1}$ Department of Forensic Medicine and Toxicology, Faculty of Veterinary Medicine Mansoura University, P.O. 35516, Mansoura, Egypt. \\ ${ }^{2}$ Department of Pathology. Faculty of Veterinary Medicine Mansoura University, P.O. 35516, Mansoura, Egypt.
}

\section{ARTICLE HISTORY}

\section{Received: 01.08.2019}

Revised: 20.08 .2019

Accepted: 23.08 .2019

Address correspondence to Eman Abd Elhafeez; Tel. 01005344462;

E-mail: eman1722013@gmail.com

\begin{abstract}
Objective: To evaluate the potential hazards of cadmium and/or chromium on the reproductive system of adult male albino rat.

Design: Randomized controlled study.

Animals: Forty mature male albino rats weighing $260 \pm 10 \mathrm{~g}$.

Procedures: Rats were allocated into four groups (ten animals each). Control group (group 1), group 2 received $4.4 \mathrm{mg} \mathrm{kg}^{-1}$ cadmium chloride, group 3 was given $2.5 \mathrm{mg} \mathrm{kg-1}$ sodium dichromate and group 4 received combination of $\mathrm{Cd}\left(2.2 \mathrm{mg} \mathrm{kg}^{-1}\right)$ and $\mathrm{Cr}(1.25 \mathrm{mg}$ $\mathrm{kg}^{-1}$ ) orally, once daily for 65 consecutive days.

Results: Exposure to $\mathrm{Cd}$ or $\mathrm{Cr}$, in particular their combination, caused a reduction in the index weights of testes, epididymis, seminal vesicle and prostate glands. They induced a reduction of sperm count and viability with an increase of abnormal sperm morphology. Interestingly, in the combination group ( $\mathrm{Cd}$ and $\mathrm{Cr}$ together), the deleterious effects were more noticeable. Pathologically, both $\mathrm{Cd}$ and $\mathrm{Cr}$ produced degenerative changes in seminiferous tubules, necrosis of spermatogenic epithelium within the testis. Moreover, the interstitial tissue of epididymis showed marked edema and prostate showed necrosis and serous exudate of lining epithelium. In the interaction group, testis showed complete degenerative changes and necrosis of spermatogenic epithelium, with marked interstitial edema and hyperplastic epithelial lining of epididymal tubules.

Conclusion and clinical relevance: The present results support the hypothesis that the testis is one of the most sensitive organs to $\mathrm{Cd}$ and/or $\mathrm{Cr}$ and that the exposure to any of them or to their combination lead to testicular damage and thereby male infertility.
\end{abstract}

Keywords: Cadmium, Chromium, Toxicity, Testes.

\section{INTRODUCTION}

Cadmium (Cd) is an environmental pollutant, produced mainly during many industries such as battery, electroplating, pigment and plastic industries. The general population is exposed to $\mathrm{Cd}$ via pollutants found in both drinking water and food. Besides industrial sources, cigarette's smoke constitutes the most important source of $\mathrm{Cd}$ [1]. The International Agency for Research on Cancer (IARC) has categorized $\mathrm{Cd}$ as a carcinogen [2]. It has been proven that acute and chronic exposure to $\mathrm{Cd}$ has several detrimental impacts on many organs, especially testes in both human and animals [3].

Exposure to $\mathrm{Cd}$ induces infertility and cancers of the reproductive tissues $[4,5]$. It has been demonstrated that $\mathrm{Cd}$ could cause haemorrhage, edema, necrosis and atrophy of the testes. In addition, it could induce a decrease in counts and motility of sperm and reduce the concentrations of testosterone in plasma and testes [6]. Exposure to $\mathrm{Cd}$ could also induce a significant increase of abnormal sperm morphology [7].

Environmental Protection Agency listed chromium as one of the most environmental toxic heavy metals for human [8]. Chromium is naturally found in rocks, volcanic dust, gasses, soils as well as plant and animals. Oxidation forms of chromium, generally present in the environment, are chromium (II), chromium (III), chromium (IV), and chromium (VI) [9]. Chromium (VI) compounds are extensively used in many industries including stainless steel production, welding, electroplating, leather tanning, production of dyes, and wood preservatives $[10,11]$. Chromium (VI) is considered one of the most toxic transition heavy metal that has deleterious effects on the male reproductive system $[12,13]$.

It can easily penetrate the cell, then goes through a chain reaction with production of chromium intermediates [14]. The reduced forms of $\mathrm{Cr}$ bind to intracellular proteins, resulting in an increase of total chromium in the blood cell. During this reduction process, chromium produces reactive oxygen species that induces oxidative stress [15]. Ingestion of hexavalent $\mathrm{Cr}$ compounds leads to degeneration in the outer layers of somniferous tubules, a decrease in the sperm count and spermatogonia per tubule, with subsequent increase in the percent of abnormal spermatozoa [16]. In male albino rat, hexavalent $\mathrm{Cr}$ induces reductions in the weights of testes, epididymis, seminal vesicles and prostate glands with a remarkable reduction in epididymal sperm number and sperm motility [17].

The combined effects of $\mathrm{Cd}$ and $\mathrm{Cr}$ on oxidative- endoplasmic reticulum-stress mediated apoptosis in the liver of mice have been investigated [18]. In a study applied on Japanese Quail eggs, the mixture of $\mathrm{Cd}$ and $\mathrm{Cr}$ decreased eggshell strength and thickness more than the individual exposure to each [19]. However, studies on the combined effects of these metals specifically on male reproductive system are scarce. Therefore, this study was delineated to evaluate the toxic effects of the exposure to $\mathrm{Cd}$ and $\mathrm{Cr}$ and their combination on the reproduction of male albino rats.

\section{MATERIAL AND METHODS}




\subsection{Animals}

Forty healthy mature male albino rats weighing $260 \pm 10 \mathrm{~g}$ were purchased from Animals Experimental Unit, Faculty of Veterinary Medicine, Zagazig University. They were placed in plastic cages with wood shavings as bedding, and were kept under controlled condition $\left(23 \pm 1{ }^{\circ} \mathrm{C}, 12 \mathrm{~h}\right.$ light and $12 \mathrm{~h}$ dark cycle). Rats were supplied with standard laboratory pelleted feed and water ad libitum. The animals were accommodated for our laboratory conditions for 2 weeks before the start of the experiment. The animal research was accomplished in agreement with the Guiding principle for the Care and Use of Laboratory Animals of the National Institutes of Health (NIH), and the study protocol was approved by Research Ethics Committee, Faculty of Veterinary Medicine, Mansoura University (M/23).

\subsection{Chemicals}

Cadmium chloride monohydrate $\left(\mathrm{CdCl}_{2} \mathrm{H}_{2} \mathrm{O}\right)$ and Sodium dichromate dihydrate (chromium VI) (Oxford Lab chem, Mumbai, India) were used in this experiment.

\subsection{Experimental design}

The experimental rats were randomly alienated into four groups (10 rats per each). (Group 1) control group was administrated $0.5 \mathrm{ml}$ distilled water per rat as a vehicle, (group 2) was administrated $\mathrm{CdCl}_{2} \mathrm{H}_{2} \mathrm{O}\left(4.4 \mathrm{mg} \mathrm{kg}^{-1} 1 / 20 \mathrm{LD}_{50}\right.$ ) [20], (group 3) was administrated $\mathrm{Cr}_{2} \mathrm{Na}_{2} \mathrm{O}_{7} .2 \mathrm{H}_{2} \mathrm{O}\left(2.5 \mathrm{mg} \mathrm{kg}^{-1} 1 / 20 \mathrm{LD}_{50}\right)$ [21], and (group 4) was administrated $\mathrm{CdCl}_{2} \mathrm{H}_{2} \mathrm{O}$ and $\mathrm{Cr}_{2} \mathrm{Na}_{2} \mathrm{O}_{7} .2 \mathrm{H}_{2} \mathrm{O}(2.2+$ $\left.1.25 \mathrm{mg} \mathrm{kg}^{-1}\right)$. The vehicle and chemicals were given orally via stomach tube, once daily for 65 consecutive days, based on a complete spermatogenic cycle in rats [22]. At the $65^{\text {th }}$ day of the experiment, animals were exposed to light anesthesia by diethyl ether.

\subsection{Determination of index weight of reproductive organs}

Rats were weighted and their reproductive organs (testes, epididymis, seminal vesicles and prostate glands) were dissected out and weighted. Their index weight (I.W.) was calculated relative to the total body weight of animals. Index weight (I.W.) = [organ weight $(\mathrm{g})$ / body weight $(\mathrm{g})] \times 100$

\subsection{Evaluation of reproductive parameters (sperm picture)}

Epididymis from each rat was collected and the caudal part was gently squeezed and seminal content was obtained and diluted with $1 \mathrm{ml}$ normal saline. Sperm count was performed using the Improved New Pauer hemocytometer. Determination of sperm viability and sperm abnormalities were measured by using equal amounts of semen and eosin-nigrosin stain (one drop each), which were mixed together, then a thin film was made using a clean glass slide and was examined with a light microscope at (40×). Eosin is a differential stain that is able to stain the head of dead sperms with red, while nigrosin stain is used for background staining. Live and dead sperms were expressed as a percent and sperm abnormalities were also determined [23].

\subsection{Histopathological examination}

Specimens from reproductive organs (testes, epididymis, seminal vesicles and prostate glands) were collected and kept in $10 \%$ neutral buffered formalin. Sections of 5-micron thickness were prepared from collected specimens, stained by hematoxylin and eosin (H\&E) and examined by light microscope [24].

\subsection{Statistical Analysis}

Data were analyzed statistically using the statistical software program (SPSS for Windows, version 20, USA). Mean and standard errors of mean for each variable was presented. Differences between groups were assessed using one-way ANOVA with post hoc Least Significance Difference (LSD). At $P<0.05$, the result was considered significant.

\section{RESULTS}

In Table 1, the index weights of reproductive organs were presented. The index weights of testes, epididymis, seminal vesicle and prostate showed significant reductions following the exposure to $\mathrm{Cd}-, \mathrm{Cr}$ - and $\mathrm{Cd}+\mathrm{Cr}$ compared to control with a significant reduction recorded in $\mathrm{Cd}+\mathrm{Cr}$ co-exposed group compared to individual exposure.

Table 1. Index weight (\%) (Mean \pm SE) of testes, epididymis, seminal vesicle and prostate of rats received Cd and or $\mathrm{Cr}$ orally for 65 days.

\begin{tabular}{llll} 
Groups & $\begin{array}{l}\text { Testicular index } \\
\text { weight (\%) }\end{array}$ & $\begin{array}{l}\text { Epididymal index } \\
\text { weight (\%) }\end{array}$ & $\begin{array}{l}\text { Seminal vesicle and prostatic index } \\
\text { weights (\%) }\end{array}$ \\
\hline Control & $0.7^{\mathrm{a}} \pm 0.007$ & $0.3^{\mathrm{a}} \pm 0.0$ & $0.8^{\mathrm{a}} \pm 0.0$ \\
$\mathrm{Cd}\left(4.4 \mathrm{mg} \mathrm{kg}^{-1}\right)$ & $0.4^{\mathrm{c}} \pm 0.0$ & $0.2^{\mathrm{b}} \pm 0.0$ & $0.6^{\mathrm{b}} \pm 0.0$ \\
$\mathrm{Cr}\left(2.5 \mathrm{mg} \mathrm{kg}^{-1}\right)$ & $0.5^{\mathrm{b}} \pm 0.0$ & $0.2^{\mathrm{b}} \pm 0.0$ & $0.6^{\mathrm{b}} \pm 0.0$ \\
$\mathrm{Cd}+\mathrm{Cr}\left(2.2+1.25 \mathrm{mg} \mathrm{kg}^{-1}\right)$ & $0.3^{\mathrm{d}} \pm 0.0$ & $0.1^{\mathrm{c}} \pm 0.0$ & $0.5^{\mathrm{c}} \pm 0.0$
\end{tabular}

In each column, the means with different superscript letters are significantly different at $\mathrm{P}<0.05$. Cd refers to cadmium treated group, $\mathrm{Cr}$ refers to chromium treated group, $\mathrm{Cd}+\mathrm{Cr}$ refers to the combination group.

Table 2: Sperm count, viability and abnormalities (Mean $\pm \mathrm{SE}$ ) in rats received Cd and or Cr orally for 65 days.

$\begin{array}{llll}\text { Groups } & \text { Sperm count }(\mathbf{1 0} / \mathrm{ml}) & \text { Sperm viability (\%) } & \text { Sperm abnormalities (\%) } \\ & & & \\ \text { Control } & 248.0^{\mathrm{a}} \pm 0.2 & 92.2^{\mathrm{a}} \pm 1.5 & 5.6^{\mathrm{c}} \pm 1.8 \\ \mathrm{Cd}\left(4.4 \mathrm{mg} \mathrm{kg}^{-1}\right) & 173.0^{\mathrm{b}} \pm 0.2 & 45.6^{\mathrm{b}} \pm 1.8 & 55.6^{\mathrm{b}} \pm 2.4 \\ \mathrm{Cr}(2.5 \mathrm{mg} \mathrm{kg} & 177.0^{\mathrm{b}} \pm 0.2 & 46.7^{\mathrm{b}} \pm 1.67 & 51.1^{\mathrm{b}} \pm 2.6 \\ \mathrm{Cd}+\mathrm{Cr}\left(2.2+1.25 \mathrm{mg} \mathrm{kg}^{-1}\right) & 124.0^{\mathrm{c}} \pm 0.2 & 28.9^{\mathrm{c}} \pm 3.1 & 73.3^{\mathrm{a}} \pm 2.4\end{array}$


In each column, the means with different superscript letters are significantly different at $\mathrm{P}<0.05$. Cd refers to cadmium treated group, Cr refers to chromium treated group, $\mathrm{Cd}+\mathrm{Cr}$ refers to the combination group.

In Table 2, sperm count, sperm viability and percent of sperm abnormalities revealed significant reductions in $\mathrm{Cd}-, \mathrm{Cr}$ - and $\mathrm{Cd}+\mathrm{Cr}$ exposed groups compared to the control group. The reduction in sperm count was more pronounced in $\mathrm{Cd}+\mathrm{Cr}$ co-exposure group. Types of sperm abnormalities were bent tail, headless sperm, banana-shaped head, undulating mid piece, folded tail, coiled head, tailless head, coiled tail, detached head and curved tail (Figure 1).

Histopathological findings in different organs of rats received $\mathrm{Cd}$ and or Cr orally for 65 days were demonstrated in Figure 2 .
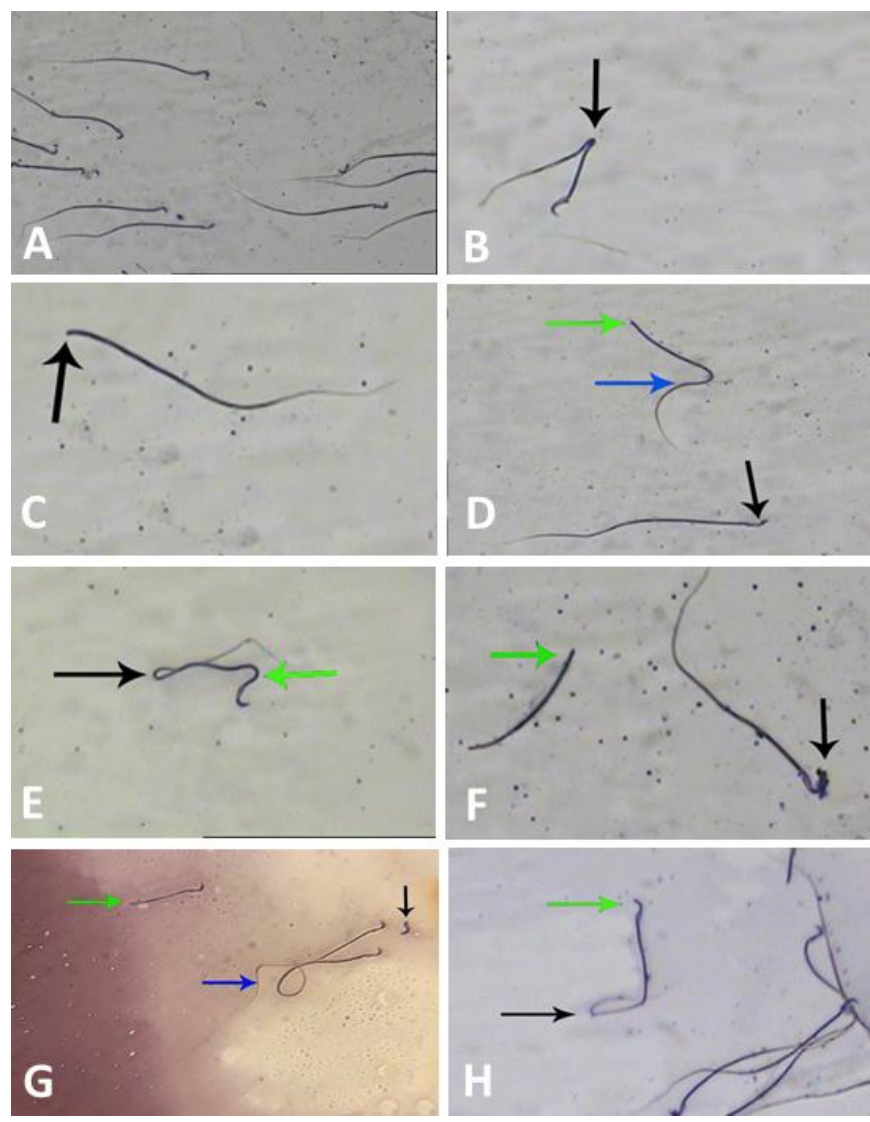

Figure 1: Types of sperm abnormalities; (A) Control sperm normal hock-shaped head (B) Bent tail of rat received Cd.; (C) Headless sperm of rat received Cd; (D) Bananashaped head (black arrow), curved tail (blue arrow), headless sperm (green arrow) of rat received $\mathrm{Cd}$; $(\mathrm{E})$ Undulating mid piece (green arrow), folded tail (black arrow) of rat received $\mathrm{Cr}$; $(\mathrm{F})$ Headless sperm (green arrow), coiled head (black arrow) of rat received $\mathrm{Cr}$; (G) Tailless head (green arrow), coiled tail (blue arrow), detached head (black arrow) of rat received $\mathrm{Cd}+\mathrm{Cr}$; $(\mathrm{H})$ Banana-shaped head (green arrow), curved tail (back arrow) of rat received $\mathrm{Cd}+\mathrm{Cr}$.

\section{DISCUSSION}

The index weight of reproductive organs is considered one of the most valuable indicator for reproductive health [25]. In the present study, sub-chronic exposure to $\mathrm{Cd}$ or $\mathrm{Cr}$ significantly reduced the index weight of reproductive organs. This decrease could be resulted from the ability of $\mathrm{Cd}$ to cause lipid peroxidation as well as oxidative damage with subsequent atrophy in the reproductive organs [26, 27]. Cadmium has the ability to cause necrotic degenerative changes in the testicular tissue leading to reduction in the testicular weight $[28,29]$. It has been also postulated that reduction in testicular weight associated with $\mathrm{Cd}$ toxicity may be due to reduction in the number of Sertoli cells and/or Leydig cells [30-32]. These results were confirmed by the histopathological analysis of the testes in the present study.

Likewise, $\mathrm{Cr}$ reduced the index weight of the reproductive organs owing to either a decrease in serum testosterone level in Cr-exposed rats [33], or the liberation of reactive radicals resulting in amplified oxidative stress damages in the sperm membranes, proteins and DNA with substantial decrease in the weight of reproductive organs [34].
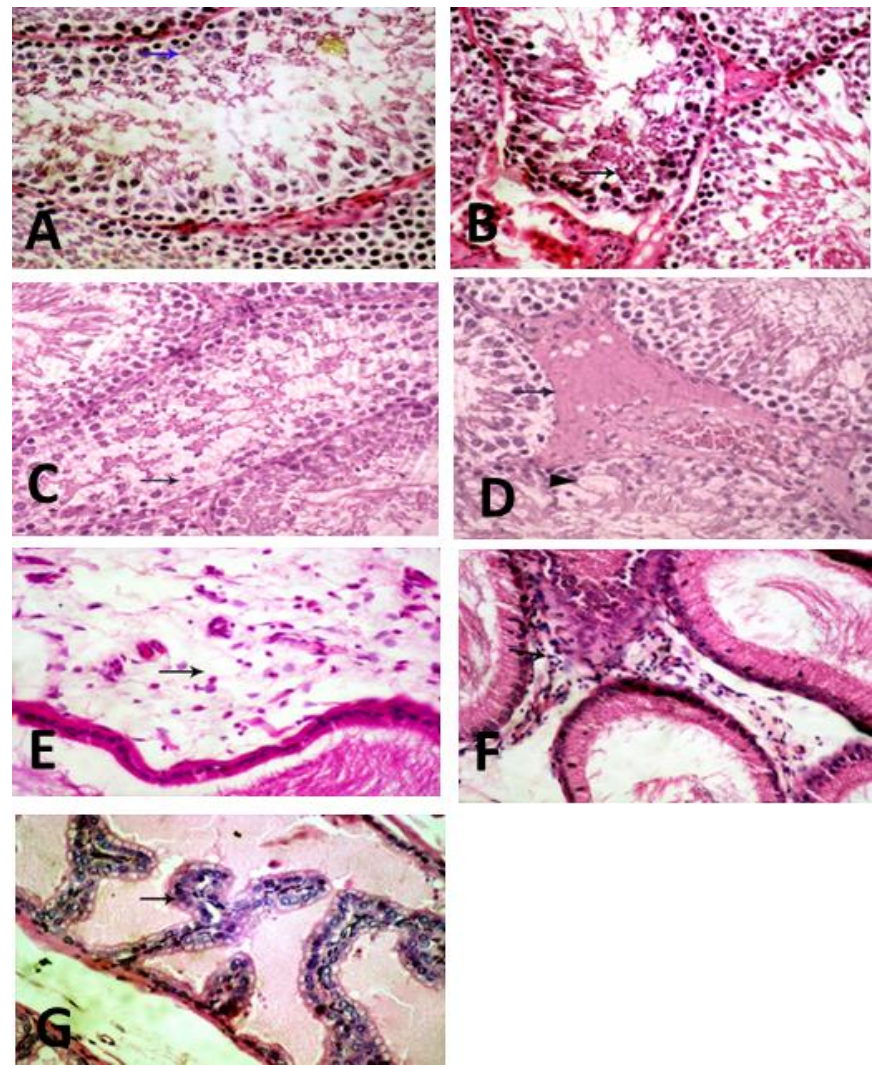

Figure 2: Histopathological finding of testicular, epididymal and prostatic tissue of rats subjected to $\mathrm{Cd}, \mathrm{Cr}$ and their combination (H\&E, 400X). (A), (B) band (C), testes show degenerative changes, and necrosis of spermatogenic epithelium in $\mathrm{Cd}, \mathrm{Cr}$, and their combination, respectively. (D) Testes of rats received $\mathrm{Cd}+\mathrm{Cr}$, show edema with eosinophilic transudate in interstitial tissue (arrow), degenerative changes and necrosis of spermatogenic epithelium (arrow head). (E) Epididymis of rats received Cd; shows marked edema in the interstitial tissue (arrow) and congestion in interstitial capillaries. (F) Epididymis of rats received $\mathrm{Cr}$, shows marked interstitial edema with round cells infiltration (arrow). (G) Prostate of rats received Cd, shows hyperplasia of glandular epithelium (arrow).

It is worthy to note that a significant decrease in the index weights of reproductive organs was noticed in $\mathrm{Cd}+\mathrm{Cr}$ co-exposed group, suggesting that exposure to $\mathrm{Cd}+\mathrm{Cr}$ in combination is much more toxic than separate exposure to each. The reduction in the index weights of reproductive system was attributed to the oxidative stress effects induced by both compounds [34,35]. Our hypothesis is supported by the result of a study on Japanese Quail eggs, where the mixture of $\mathrm{Cd}$ and $\mathrm{Cr}$ produced more reductions in the weights of eggs more than the individual exposure to each [19]. The present result is an in agreement with that of previous results [36].

Semen analysis showed that sub chronic exposure to $\mathrm{Cd}$ and $\mathrm{Cr}$ resulted in a significant decrease in total sperm count and 
viability with a significant increase in the percent of sperms with abnormal morphology. Cadmium induced damage to the testicular germinal epithelium, the Leydig cells and the Sertoli cells resulting in testicular and cellular damage which adversely affected sperm characters [7, 26]. Exposure to $\mathrm{Cd}$ disrupted the tight junctions between Sertoli cells and altered germ cell adhesion with consequent exfoliation of immature cells into the lumen of seminiferous tubules, leading to a decrease in viable sperm count [37]. In the current study, the significant increase in sperm abnormalities could be attributed to the excessive production of oxidative stress byproducts with eventual cellular death [28, 38].

Following $\mathrm{Cr}$ - exposure, the alteration in sperm parameters might be attributed to the impairment in steroidogenic mechanisms and hormonal derangement. In male rabbits, the alteration in sperm parameters associated with $\mathrm{Cr}$ - exposure has been explained as a result of decreased serum concentration of testosterone and increased serum concentration of FSH [39]. Taken together, generation of ROS and peroxidation of sperm membranes have a harmful effect on sperm motility and morphology [40].

Our results suggest that $\mathrm{Cd}$ and $\mathrm{Cr}$ together generate additive or synergistic toxic effects that lead to more pronounced decrease in sperm count, viability and an increase in sperm abnormalities compared to the separate exposure to each. Our hypothesis could be supported by the result of Skalická et al.' work on Japanese Quail eggs [19].

The histopathological findings where the testes and other reproductive organs showed marked pathological alterations could also support our hypothesis. Previous studies suggested that oxidative stress, lipid peroxidation, depletion of antioxidant defense systems and high production of pro-inflammatory mediators were involved in the pathological alterations of cadmium-induced testicular toxicity [41].

The testis is extremely sensitive to Cd toxicity, which causes profound testicular damage $[29,42]$. In the present investigation, the testes of Cd-treated rats exhibit degeneration, necrosis and atrophy of almost all of the seminiferous tubules [43]. Such findings coincide with that of previous reports [44, 45].

Similarly, $\mathrm{Cr}$ could exert pathological alterations in reproductive organs in $\mathrm{Cr}$-exposed rats [46]. Also, $\mathrm{Cr}$ caused a significant decrease in the thickness of epithelia of seminiferous tubules and this is suggested to be as a result of the degenerative changes and accumulation of sloughed cells in tubule lumen [47]. Our results agree with the results of studies conducted on male reproductive organs in rats $[33,48]$.

Testis subjected to the combination of $\mathrm{Cd}$ and $\mathrm{Cr}$ showed complete degenerative changes and necrosis of reproductive organs. This may be due to accumulation of $\mathrm{Cd}$ and $\mathrm{Cr}$ in testis and epididymis. In a previous study in male Sprague Dawley rats, $\mathrm{Cd}$ and $\mathrm{Cr}$ combination induced organelle damage associated with the accumulation of both elements in the nuclei and mitochondria of the liver and kidney. At these sites, the metals can induce DNA- and protein damage and lipid peroxidation with subsequent functional changes in the target tissues and organs [49-51].

\section{Conclusion}

Co-exposure to $\mathrm{Cd}$ and $\mathrm{Cr}$ in male rats induces extra reproductive toxicity than single exposure, especially in sperm parameters. Consequently, environmental pollution with both elements may have significant clinical problems.

\section{Conflict of interest statement}

The authors declare that there is no any conflict of interest in the current research work.

\section{Research ethics committee permission}

The current research work was permitted to be executed according to standards of Animal Research Committee of Faculty of Veterinary Medicine, Mansoura University.

\section{Author contributions}

A. A. H. conducted the experiment and analytical procedures; E. M. Abd E. performed sample collection, statistical analysis, drafting and submission of the manuscript; M. F. H. conducted histopathological examination; M. M. A. revised the manuscript.

\section{REFERENCES}

[1] Arafa MH, Mohammad NS, Atteia HH. Fenugreek seed powder mitigates cadmium-induced testicular damage and hepatotoxicity in male rats. Exp Toxicol Pathol 2014;66:293-300.

[2] IARC. Beryllium, cadmium, mercury, and exposures in the glass. IARC Working Group on the Evaluation of Carcinogenic Risks to Humans: Beryllium, Lyon, 1993.

[3] Thompson J, Bannigan J. Cadmium: Toxic effects on the reproductive system and the embryo. Rep Toxic 2008;25:304-15.

[4] Goyer RA, Liu J, Waalkes MP. Cadmium and cancer of prostate and testis. Biometals 2004;17:555-8.

[5] Akinloye O, Arowojolu AO, Shittu OB, Anetor JI. Cadmium toxicity: a possible cause of male infertility in Nigeria. Reprod Biol 2006;6:17-30.

[6] Ognjanović BI, Marković SD, Đorđević NZ, Trbojević IS, Štajn AŠ, Saičić ZS. Cadmium-induced lipid peroxidation and changes in antioxidant defense system in the rat testes: Protective role of coenzyme Q10 and Vitamin E. Rep Toxic 2010;29:191-7.

[7] Elbaghdady HAM, Alwaili MA, El-Demerdash RS. Regenerative potential of bone marrow mesenchymal stem cells on cadmium chlorideinduced hepato-renal injury and testicular dysfunction in sprague dawley rats. Ecotoxicol Environ Saf 2018;164:41-9.

[8] Gupta S, Singh S, Sunita S. Tolerance against heavy metal toxicity in cyanobacteria: role of antioxidant defense system. IJHSP 2015;7:9-16.

[9] Testa S, Jacobs J. Overview of Chromium (VI) in the Environment. Chromium (VI) Handbook: CRC Press; 2005. p. 1-21.

[10] Ahmed A, Ahmed SN. Obesity Medical Management. IJRAP 2014;5:6973.

[11] Agency for Toxic Substances and Disease Registry. Toxicological Profile for Chromium. Atlanta: U. S. Department of Health and Human Services. ATSDR 2000:7440-7.

[12] Oliveira H, Spanò M, Guevara MA, Santos TM, Santos C, Pereira MdL. Evaluation of in vivo reproductive toxicity of potassium chromate in male mice. Exp Toxicol Pathol 2010;62:391-404.

[13] Samuel JB, Stanley JA, Vengatesh G, Princess RA, Muthusami S, Roopha DP, Suthagar E, Kumar KM, Sebastian MS, Aruldhas MM. Ameliorative effect of vitamin $C$ on hexavalent chromium-induced delay in sexual maturation and oxidative stress in developing Wistar rat ovary and uterus. Toxi Ind H 2012;28:720-33.

[14] Valko M, Rhodes CJ, Moncol J, Izakovic M, Mazur M. Free radicals, metals and antioxidants in oxidative stress-induced cancer. Chem Biol Interact 2006;160:1-40.

[15] Chelikani P, Ramana T, Radhakrishnan TM. Catalase: A repertoire of unusual features. Indian J Clin Biochem 2005;20:131-5.

[16] Acharya UR, Mishra M, Tripathy RR, Mishra I. Testicular dysfunction and antioxidative defense system of Swiss mice after chromic acid exposure. Rep Toxic 2006;22:87-91.

[17] Saha J, Choudhuri S, Choudhuri D. Effect of Sub-Chronic Exposure to Chromium on Haematological and Biochemical Parameters of Male Albino Rat. Asian J Pharm Clin Res 2017;10:345.

[18] Jin Y, Zhang S, Tao R, Huang J, He X, Qu L, Fu Z. Oral exposure of mice to cadmium (II), chromium (VI) and their mixture induce oxidative- 
and endoplasmic reticulum-stress mediated apoptosis in the livers. Envir Toxic 2014;31:693-705.

[19] Skalická M, Koréneková B, Nad' P, Šály J. Influence of Chromium and Cadmium Addition on Quality of Japanese Quail Eggs. Acta Veterinaria Brno 2008;77:503-8.

[20] USAF. Armstrong Aerospace Medical Research Laboratory , Wright Patterson AFB, OH. In: G H, editor. Installation Restoration Program Toxicology Guide Volume 5. vols. GRA and I: USAF; 1990.

[21] Bagchi D, Hassoun EA, Bagchi M, Muldoon DF, Stohs SJ. Oxidative stress induced by chronic administration of sodium dichromate $[\mathrm{Cr}(\mathrm{VI})]$ to rats. Comp Biochem Physiol C Pharmacol Toxicol Endocrinol 1995;110:281-7.

[22] Russell L, Ettlin R, Sinha Hikim A, Clegg E. The classification and timing of spermatogenesis. Histological and histopathological evaluation of the testis. vols. 1: J Cell Biochem; 1990. 41-58

[23] Ikpeme EV, Udensi O, Ekaluo UB, Uyoh EA, Asuquo BO, Udoh FV, Udoh PB. Effect of crude extract of carica papaja seeds on the reproductive efficiency of male albino rats. G J Pure Appl Sci 2007;13:365-8.

[24] Suvarna K, Layton C. Bancroft's Theory and Practice of Histological Techniques E-Book: Elsevier Health Sciences. Churchill Livingstone, Australia: Elsevier H Sci; 2012.

[25] Choudhary N, Goyal R, Joshi S. Effect of malathion on reproductive system of male rats. J envir biol 2008;29:259-63.

[26] El-Demerdash FM, Yousef MI, Kedwany FS, Baghdadi HH. Cadmiuminduced changes in lipid peroxidation, blood hematology, biochemical parameters and semen quality of male rats: protective role of vitamin E and $\beta$-carotene. Food Chem Toxicol 2004;42:1563-71.

[27] Acharya UR, Mishra M, Patro J, Panda MK. Effect of vitamins C and E on spermatogenesis in mice exposed to cadmium. Rep Toxic 2008;25:848.

[28] El-Shahat AE-R, Gabr A, Meki A-R, Mehana E-S. Altered Testicular Morphology and Oxidative Stress Induced by Cadmium in Experimental Rats and Protective Effect of Simultaneous Green Tea Extract. Folia Morphol (Warsz) 2009;27:757-64.

[29] de Souza Predes F, Diamante MAS, Dolder H. Testis response to low doses of cadmium in Wistar rats. Int J Clin Exp Pathol 2010;91:125-31.

[30] Farombi EO, Adedara IA, Akinrinde SA, Ojo OO, Eboh AS. Protective effects of kolaviron and quercetin on cadmium-induced testicular damage and endocrine pathology in rats. Andrologia 2012;44:273-84.

[31] Abdelrazek HMA, Helmy SA, Elsayed DH, Ebaid HM, Mohamed RM. Ameliorating effects of green tea extract on cadmium induced reproductive injury in male Wistar rats with respect to androgen receptors and caspase- 3. Rep Bio 2016;16:300-8.

[32] Chemek M, Venditti M, Boughamoura S, Mimouna SB, Messaoudi I, Minucci S. Involvement of testicular DAAM1 expression in zinc protection against cadmium-induced male rat reproductive toxicity. J Cell Physiol 2017;233:630-40.

[33] Chandra AK, Chatterjee A, Ghosh R, Sarkar M. Effect of curcumin on chromium-induced oxidative damage in male reproductive system. Environ Toxicol Pharmacol 2007;24:160-6.

[34] Akunna GG, Ogunmodede OS, Saalu CL, Ogunlade B, Bello AJ, Salawu EO. Ameliorative effect of Moringa oleifera (drumstick) leaf extracts on chromium-induced testicular toxicity in rat testes. W J Life Sci Med Res 2012;2:20-4.

[35] Wang Y, Fang J, Leonard SS, Krishna Rao KM. Cadmium inhibits the electron transfer chain and induces Reactive Oxygen Species. Free Radic Biol Med 2004;36:1434-43.

[36] Uyanik F, Kaya Ş, Kolsuz AH, Eren M, Şahin N. The effect of chromium supplementation on egg production, egg quality and some serum parameters in laying hens. Turk J Vet Anim Sci 2002;26:379-87.
[37] Hew KW, Ericson WA, Welsh MJ. A Single Low Cadmium Dose Causes Failure of Spermiation in the Rat. Toxicol Appl Pharmacol 1993;121:15-21.

[38] Sen Gupta R, Kim J, Gomes C, Oh S, Park J, Im W-B, Seong JY, Ahn RS, Kwon H-B, Soh J. Effect of ascorbic acid supplementation on testicular steroidogenesis and germ cell death in cadmium-treated male rats. Mol Cell Endocrinol 2004;221:57-66.

[39] Yousef MI, El-Demerdash FM, Kamil KI, Elaswad FAM. Ameliorating effect of folic acid on chromium(VI)-induced changes in reproductive performance and seminal plasma biochemistry in male rabbits. Rep Toxic 2006;21:322-8.

[40] Kim J, Parthasarathy S. Oxidation and the Spermatozoa. Semin Reprod Med 1998;16:235-339.

[41] Fouad AA, Jresat I. Thymoquinone therapy abrogates toxic effect of cadmium on rat testes. Andrologia 2014;47:417-26.

[42] Oguzturk H, Ciftci O, Aydin M, Timurkaan N, Beytur A, Yilmaz F. Ameliorative effects of curcumin against acute cadmium toxicity on male reproductive system in rats. Andrologia 2012;44:243-9.

[43] El-Neweshy MS, El-Maddawy ZK, El-Sayed YS. Therapeutic effects of date palm (Phoenix dactyliferaL.) pollen extract on cadmium-induced testicular toxicity. Andrologia 2012;45:369-78.

[44] Liu X-R, Wang Y-Y, Fan H-R, Wu C-J, Kumar A, Yang L-G. Preventive Effects of $\beta$-cryptoxanthin against cadmium-induced oxidative stress in the rat testis. Asian J Androl 2016;0:0.

[45] Chen N, Su P, Wang M, Li Y-M. Ascorbic acid inhibits cadmium-induced disruption of the blood-testis barrier by regulating oxidative stressmediated p38 MAPK pathways. Environ Sci Pollut Res Int 2018;25:21713-20.

[46] Naseer MI, Zaigham K, Malik A, Habiba UE, Alam R, Manan A, Arooj M, Saeed A, Qazi MH, Asif M, Rasool M. Potential reproductive health effects and oxidative stress associated with exposure to potassium dichromate (K2CR2O7) and magnesium sulphate (MgSO4) in male mice. Pak J Med Sci 2014;30.

[47] Z. Kh. Jeber ZKJ. Effect of Turmeric Oil on Reproductive Efficiency of Adult Male Rats Exposed to Potassium Dichromate. IOSR J Environ Sci Toxicol Food Technol 2013;3:52-8.

[48] Al-Mukhtar N, Mohmmed A, Mahdi H. The effects of potassium dichromate on testes, accessory sex glands, liver and kidney in adult male rats treated with ascorbic acid. Aust J Basic Appl Sci 2016;10:99108.

[49] Venter C, Oberholzer HM, Cummings FR, Bester MJ. Effects of metals cadmium and chromium alone and in combination on the liver and kidney tissue of male Spraque-Dawley rats: An ultrastructural and electron-energy-loss spectroscopy investigation. Microsc Res Tech 2017;80:878-88

[50] Stols G, Ferreira R, Pelser A, Olivier WA, Van der Merwe A, De Villiers C, Venter S. Perceptions and needs of South African Mathematics teachers concerning their use of technology for instruction. AJOL 2015;35:1-13.

[51] Madejczyk MS, Baer CE, Dennis WE, Minarchick VC, Leonard SS, Jackson DA, Stallings JD, Lewis JA. Temporal Changes in Rat Liver Gene Expression after Acute Cadmium and Chromium Exposure. PLoS One 2015;10:e0127327. 